\title{
WANITA KARIER PERSPEKTIF ISLAM
}

\author{
Rahma Pramudya Nawang Sari, M.HI \\ rahmapramudya.pns@gmail.com \\ Anton, M.PdI \\ antonbima67@gmail.com \\ Universitas Muhammadiyah Kupang
}

\section{Abstrak}

Dewasa ini, hampir di setiap lembaga-lebaga dipenuhi oleh pekerja wanita, dari lembaga negara sampai dunia pendidikan. Di mall-mall dan super market, hampir semua dipenuhi oleh pekerja wanita. Menurut penulis, fenomena ini berawal sekitar awal tahun 90-an yang sebelumnya pekerjaan banyak di pegang oleh kaum pria. Harus diakui bahwa perbandingan jumlah pria dan wanita saat ini di Indonesia memilki jumlah yang hampir sama. Namun disisi lain akibat pekerjaan banyak diambil alih oleh kaum wanita, banyak kaum pria yang pada akhirnya menganggur atau tidak memiliki pekerjaan. Selain itu, oleh semakin berkembangnya keadaan, semakin berkembang pula keinginan wanita untuk terus maju dan mengembangkan kariernya dalam dunia perkerjaan. Wanita-wanita pekerja ini biasa disebut dengan wanita karier yang oleh sebagian ulama berbeda pendapat terkait hal tersebut. Sebagian membolehkan dengan syarat dan sebagian lain melarangnya secara mutlak karena selain menyababkan banyak kaum pria yang menjadi pengangguran akibat hal tersebut dan dampak yang lebih besar lagi adalah, dikhawatirkan lupa akan kewajibannya sebagai seorang istri, yaitu melayani suami atau keluarga di rumah. 


\section{Keyword: Wanita Karier, Pendapat Ulama, Perspektif Islam.}

\section{A. Pendahuluan}

Persoalan wanita karier dan keikutsertaannya dalam berbagai aktivitas publik adalah isu yang hingga kini masih diperdebatkan. Sebagian orang berpendapat, wanita dapat memperoleh apresiasi akan jati dirinya dengan bekerja dan aktif di sektor kehidupan luar rumah tangga. Bagi mereka, terjunnya wanita ke dunia karier bermakna positif, tidak saja bagi wanita sendiri, melainkan juga bagi keluarganya. Sementara sebagian yang lain menilai keikutsertaan wanita dalam beragam aktivitas publik, termasuk meniti karier di luar rumah tangga, adalah sesuatu yang negatif. Bagi mereka, wanita yang bekerja di luar sektor domestik dapat merendahkan martabat wanita dan melalaikan tugas-tugas yang seharusnya diembannya, yaitu tugas kerumahtanggaan. Mereka menganggap wanita sebagai mahluk domestik yang tidak boleh berkecimpung dalam urusan publik. Seringkali, kedua pandangan yang bersebrangan itu pro maupun kontra didasarkan atas dalil atau tafsir agama. ${ }^{1}$

Bagi kelompok yang mengapresiasi wanita bisa bekerja di sektor publik meyakini bahwa Islam adalah "agama ramah perempuan." Islam adalah agama yang bertujuan untuk mewujudkan persaudaraan universal (universal brotherhood), kesetaraan (equality) dan keadilan sosial (social justice). ${ }^{2}$ AlQur'an sebagai rujukan utama umat Islam dipandang berprinsip melawan segala bentuk ketidakadilan, termasuk eksploitasi ekonomi, penindasan politik, dominasi budaya, dominasi gender, dan segala bentuk disequilibrium dan

1 Masdar F. Mas'ud, Islam dan Hak Reproduksi Perempuan (Bandung: Mizan, 1997), h. 74.

2 Asghar Ali Engineer, Islam dan Teologi Pembebasan, alih bahasa Agung prihantoro, cet.ke-1 (Yogyakarta: Pustaka Pelajar, 1999), hlm. 33. 
apertheit. ${ }^{3}$ Karena itu, keikutsertaan wanita dalam sektor publik seperti tampak dalam wanita karier, tidak melanggar ajaran Islam bahkan bagian dari ajaran Islam itu sendiri.

Sementara bagi kelompok yang tidak mau mengapresiasi keikutsertaan wanita dalam aktivitas publik, termasuk dalam soal wanita karier melandaskan argumentasinya pada sisi normatif Islam yang menurut mereka secara tegas membatasi ruang gerak perempuan hanya sebatas wilayah domestik, itupun dengan pola hirarkis, di mana perempuan ditempatkan sebagai mahluk kedua di bawah lakilaki. Dalam hal ini sering diungkapkan sejumlah ayat tentang penciptaan Hawa, kepemimpinan laki-laki atas perempuan, poligami, hak-hak unilateral kaum laki-laki untuk bercerai, hak-hak kewarisan dan otoritas kesaksian hukum laki-laki yang lebih besar, tampak secara langsung memarginalkan perempuan, juga sejumlah hadits misoginis, ${ }^{4}$ seperti; hadits tentang pelarangan menyerahkan urusan pada kaum perempuan, hadits yang menyatakan bahwa keledai, anjing dan perempuan dapat membatalkan shalat, hadits tentang sujud kepada suami, serta kitab-kitab klasik yang menggambarkan perempuan sebagai separuh harga laki-laki, objek, dan sebagai mahluk domestik. ${ }^{5}$ Dari sejumlah teks ini, mereka meyakini perempuan sebagai mahluk domestik yang tidak berhak

3 Mansour Fakih, "Fiqh Sebagai Paradigma Keadilan," dalam Noor Ahmad, dkk., Epistemologi Syara': Mencari Format Baru Figh Indonesia, cet.ke-1 (Yogyakarta: Pustaka Pelajar, 2000), hlm. 143.

${ }^{4}$ Hadis Misoginis ialah hadis yang isinya membenci kaum perempuan. Istilah ini dipakai Fatima Mernissi untuk menyebut hadis-hadis yang melecehkan kaum perempuan. lihat Fatima Mernissi, Wanita di dalam Islam, alih bahasaYaziar Radianti, (Bandung: Pustaka, 1994), hlm. 62.

5 Masdar F. Mas'udi, "Perempuan diantara Lembaran Kitab Kuning," dalam Mansour Fakih, dkk., Membincang feminisme: Diskursus Gender Perspektif Islam, (Surabaya: Risalah Gusti, 1996), hlm. 167-176. 
berpartisipasi di sektor publik, bahkan keluar rumah pun harus seizin suami.

Lepas dari perdebatan di atas, persoalan wanita karier sebenarnya tidak hanya menyangkut aspek normatif ajaran Islam 'apakah boleh atau tidak boleh' lebih dari itu, adanya wanita karier juga menyentuh aspek psikologis dan sosiologis keluarga. Misalnya, wanita yang bekerja di luar rumah seringkali harus menanggung beban ganda, di samping harus mengurusi urusan rumah tangga dan keluarga, juga mesti bertanggung jawab pada pekerjaannya. Belum lagi persoalan yang secara psikologis di alami suami dan anak ketika istri harus bekerja dan banyak menghabiskan waktu di luar rumah, tidak mustahil perkawinan dan keluarga menjadi tidak stabil lagi.

Dari sini menjadi jelas bahwa persoalan wanita karier bukan persoalan sederhana. Selain terkait dengan kesetaraan antara laki-laki dan perempuan, persoalan wanita karier juga berhubungan dengan terciptanya tujuan perkawinan dan konstruksi keluarga yang terbangun. Karena itu, pertanyaan pokoknya sekarang adalah apakah dalam Islam wanita diperbolehkan beraktivitas di wilayah publik, termasuk menjadi wanita karier? Bila jawabannya "tidak," apa alasannya, dan bila jawabannya "ya" apa argumentasinya.

Tulisan ini berusaha mengurai berbagai persoalan tentang wanita karier, mulai dari konsepsi wanita karier, dampaknya secara psikologis bagi perkawinan dan keluarga, hingga mencoba melihat persoalan wanita karier dari perspektif Islam. Untuk memudahkan kajian ini, tulisan ini disusun melalui pendahuluan, pengertian dan klasifikasi wanita karier di bagian pertama dan kedua. Pada bagian ketiga dibahas sisi psikologis dari wanita karier, disusul dengan pembahasan wanita karier dalam perspektif Islam pada bagian 
keempat. Pada bagian kelima atau bagian akhir tulisan ini ditulis kesimpulan.

\section{B. Wanita Karier: Pengertian dan Klasifikasi}

\section{Definisi Wanita Karier}

Secara etimologis, wanita karier adalah gabungan dari dua kata, yaitu "wanita" dan "karier". Kata"wanita" berarti perempuan dewasa. Sementara "karier" memiliki dua pengertian, yaitu: pertama, perkembangan dan kemajuan dalam kehidupan, pekerjaan dan jabatan. Kedua, pekerjaan yang memberikan harapan untuk maju. ${ }^{6}$ Kata "karier" sendiri sering dihubungkan dengan tingkat jenis atau pekerjaan seseorang. Misalnya, wanita karier bisa dikatakan sebagai wanita yang bergulat dalam kegiatan profesi (usaha dan perusahaan). ${ }^{7}$ Dari sini bisa dirumuskan bahwa konsep wanita karier meliputi; pertama, wanita yang aktif melakukan kegiatan-kegiatan untuk mencapai suatu kemajuan. Kedua, kegiatan itu berupa kegiatan professional sesuai bidang yang ditekuninya. Ketiga, bidang pekerjaan itu dapat mendatangkan kemajuan. Sehingga bisa dikatakan bahwa wanita karier merupakan wanita yang menekuni satu atau beberapa bidang pekerjaan berdasarkan keahlian tertentu yang dimilikinya untuk mencapai kemajuan dalam hidup, pekerjaan, atau jabatan. Beberapa istilah yang sering diidentikan dengan "wanita karier," yaitu: wanita bekerja dan Tenaga Kerja Wanita (TKW). ${ }^{8}$

6 Anton M. Muleono, Kamus Besar Bahasa Indonesia, cet. II, (Jakarta: Departemen Pendidikan dan Kebudayaan, 1989), hal. 1007

7 Peter salim dan Yeni Salim, Kamus Besar Bahasa Indonesia Kontemporer (Jakarta: English Press, 1991), hlm. 1125.

${ }^{8}$ Wanita pekerja sendiri adalah mereka yang berkarya dan hasil karyanya itu ia mendapat imbalan uang. Ciri utama dari wanita pekerja ini adalah penekanannya pada imbalan yang diberikan. Artinya, pekerjaan wanita pekerja tidak harus ikut kepada orang lain, melainkan bisa juga bekerja mandiri,

Sangaji Jurnal Pemikiran Syariah dan Hukum 
Pembahasan "wanita karier' sendiri menekankan pada kata "karier". Meski dalam banyak hal wanita karier sering diidentikan dengan masalah financial, tapi sebenarnya financial bukanlah tujuan satu-satunya. Artinya, "Karier" tidak selalu bermakna uang, melainkan juga dikonotasikan sebagai tangga, hierarki dan struktur organisasi, yang melibatkan perencanaan matang dan memungkinkan bagi seseorang untuk meningkatkan posisi atau jabatan di lingkungan kerjanya. ${ }^{9}$ Dengan demikian, tidak semua wanita yang bekerja di luar rumah dapat diklaim sebagai wanita karier. Karier adalah profesi yang ditekuni secara serius untuk mencapai status setinggi-tingginya dalam hierarkhi organisasi di lingkungan kerja. Dalam karier, keberhasilan kerja tidak hanya diukur dengan capaian materi, melainkan juga ditentukan oleh prestasi kerja, yang pada gilirannya menjadikan seseorang mencapai kedudukan tinggi dalam organisasi dan mendapat status sosial dalam masyarakat.

Sampai di sini bisa dipahami bila dikatakan, wanita karier, di samping bekerja untuk mendapatkan upah atau gaji, juga untuk memperoleh prestasi tinggi menurut

sepanjang apa yang dilakukannya itu menghasilkan uang. Karena itu, wanita pekerja bisa lebih tinggi atau rendah kedudukannya dari wanita karier. Sementara TKW adalah wanita yang bisa melakukan pekerjaan di dalam atau di luar hubungan kerja guna menghasilkan barang atau jasa dalam rangka memenuhi kebutuhan masyarakat. Ciri utama dari wanita ini adalah kemampuannya dalam melakukan pekerjaan, memiliki kedudukan dan penghasilan tinggi, sekaligus tidak identik dengan pembantu rumah tangga, dokter, para ahli dan sejenisnya. Omas Ihrami, "Wanita Bekerja dan Masalahmasalahnya," dalam Toety Herarty Nurhdi dan Aida Fitalaya s. Hubeis (ed), Dinamika Wanita Indonesia: multidimensional, (Jakarta: Pusat Pengembangan Sumber Daya Wanita, 1990), hlm. 38

9 E. Kristi Poerwandari, "Aspirasi Perempuan Dan Aktualisasinya" dalam T.O Ihromi (Peny.), Kajia Wanita Dalam Pembangunan Jakarta, (Jakarta: Yayasan Obor Indonesia, 1995), hlm. 331. 
ketetapan penyelesaian suatu pekerjaan. Dalam konteks ini, wanita karier mengetahui kapan dan bagaimana sebuah pekerjaan harus diselesaikan dengan baik. Selain itu, ia juga mampu mengontrol pekerjaan dan ingkungan tempat kerjanya sehingga membuat pekerjaannya lebih efisien dan teratur.

\section{Klasifikasi Wanita Karier}

Dari sisi keterikatannya, wanita karier bisa dikelompokan kepada dua bagian, yaitu: ${ }^{10}$ pertama, wanita karier yang tidak terikat dengan tali perkawinan, yakni wanita karier yang belum menikah atau wanita yang pernah menikah tetapi telah bercerai. Wanita karier semacam ini bisa bekerja dengan bebas. Kedua, wanita karier yang terikat dengan tali perkawinan, yaitu wanita karier yang telah melangsungkan pernikahan. Wanita karier golongan ini tidak bebas bekerja melainkan terikat oleh berbagai hal, termsuk hak dan kewajiban sebagai istri. Dalam tulisan ini, wanita yang dibahas adalah wanita karier tipe kedua.

Dalam karier yang bersifat long-run atau fulltime, wanita karier berbeda sikap dalam menjalani pekerjaaanya, yaitu: ${ }^{11}$ Pertama, wanita yang menempuh karier secara terinterupsi, yakni dalam jangka waktu tertentu atau untuk sementara waktu ia berhenti dari profesi yang ditekuni disebabkan ada tugas yang lainnya. Kedua, wanita karier menempuh pola double track, yaitu kedua tugas (publik dan domestik) dijalani secara bersamaan. Ketiga, wanita karier menempuh pola stabil, yakni memprioritaskan pekerjaan atau kariernya dengan meninggalkan atau menomor-

10 Lihat misalnya Bauna'i, “Wanita Karier dalam Perspektif Hukum Islam," KARSA, Vol. 11 (Mei 2001), hlm. 99.

11 E. Kristi Poerwandari, "Aspirasi Perempuan Dan Aktualisasinya", hlm. 340 .

Sangaji Jurnal Pemikiran Syariah dan Hukum 
duakan tugas lainnya, baik yang domestik maupun publik. Kelompok yang terakhir ini menekuni karier secara total yang dalam tingkat tertentu berefek negatif bagi keluarga. Misalnya, meninggalkan rumah karena sibuk bekerja bisa berpotensi merusak keharmonisan rumah tangga, meski keharmonisan itu sendiri tidak hanya menjadi tanggung jawab istri. Lain halnya ketika wanita yang berkarier itu masih mempunyai komitmen yang sama tingginya antara pekerjaan dan rumahtangga. Seperti di Indonesia, di mana banyak diantara wanita yang berkarier masih mengutamakan keluarga dibandingkan pekerjaan. ${ }^{12}$

\section{Sisi Psikologis Wanita Karier}

\section{Alasan Wanita karier}

Fenomena wanita karier muncul dan tumbuh tidak berada di ruang hampa. Terdapat banyak faktor yang mendorong kaum hawa beralih menjadi wanita karier, misalnya; seorang wanita akan terjun di dunia kerja karena didorong oleh faktor pendidikan, di mana pendidikan bisa melahirkan wanita ahli dalam berbagai bidang, yang pada gilirannya mampu meniti karier dalam bidang tersebut; faktor keterpaksaan kondisi dan kebutuhan; faktor kemandirian ekonomi, seperti agar tidak bergantung pada suami; motif mencari kekayaan; motif mengisi waktu luang atau kesenangan; dan motivasi untuk mengembangkan bakat. ${ }^{13}$ Artinya, wanita memiliki berbagai alasan ketika hendak memutuskan untuk bekerja di luar rumah.

12 Juwairiah Dahlan, Peranan Wanita dalam Islam: Studi tentang Wanita karier dan Pendidikan Anak (Yogyakarta: Disertasi IAIN Sunan Kalijogo, Tidak diterbitkan, 2000), hlm. 403-405.

13 Huzaemah T. Yanggo, Fiqih Perempuan Kontemporer, (Yogyakarta: Almawardiprima, 2001), hlm. 94. 
Secara simplistik, terdapat tiga alasan mengapa wanita memilih bekerja di luar rumah, yaitu: ${ }^{14}$ pertama, alasan kebutuhan ekonomi (financial). Hal ini terkait dengan kebutuhan rumah tangga yang begitu besar dan mendesak yang memaksa suami dan istri bekerja agar dapat memenuhi kebutuhan sehari-hari. Dalam kondisi ini istri tidak mempunyai pilihan lain kecuali ikut mencari pekerjaan di luar rumah.

Kedua, kebutuhan sosial-relasional, yakni alasan beberapa wanita yang tetap memilih bekerja karena mempunyai kebutuhan sosial-relasional yang tinggi, yang kemudian mereka dapatkan di tempat kerja. Faktor ini terkait dengan diri wanita sendiri yang menyimpan hasrat akan terpenuhinya kebutuhan pengakuan (status) dan identitas sosial yang diperoleh melalui komunitas kerja. Karena itu, bagi wanita karier semacam ini, bergaul dengan rekan-rekan di kantor misalnya dipandang sebagai dunia yang lebih menyenangkan dari pada hanya tinggal di rumah. Selain faktor diri, faktor psikologis dan keadaan internal dalam keluarga juga bisa mempengaruhi seseorang untuk tetap bekerja di luar rumah.

Ketiga, kebutuhan aktualisasi diri, di mana wanita bekerja untuk mengaktualisasikan dirinya, berkarya, mengekspresikan dan mengembangkan diri dan orang lain, membagikan ilmu dan pengalaman, menemukan dan menghasilkan sesuatu, serta mendapatkan penghargaan atau prestasi. Kini, kebutuhan akan aktualisasi diri melalui karier ini diyakini merupakan salah satu pilihan yang banyak diambil oleh para wanita, terutama dengan makin

${ }^{14}$ Uraian lengkap tentang alasan-alasan ini bisa dilihat dalam Journal of Marriage and the Family atau http://www.ibubekerja.info/tag/ibu-bekerja. Akses tanggal 25 Maret 2012.

Sangaji Jurnal Pemikiran Syariah dan Hukum 
terbukanya kesempatan untuk meraih jenjang karier yang lebih tinggi.

Bagi wanita yang sebelum menikah sudah bekerja karena dilandasi oleh kebutuhan aktualisasi diri yang tinggi, cenderung akan kembali bekerja setelah menikah dan mempunyai anak. Mereka merasa bekerja adalah hal yang sangat bermanfaat untuk memenuhi kebutuhan aktualisasi diri, membangun kebanggaan diri, dan juga mendapatkan kemandirian secara finansial. Sebuah studi tentang kepuasan hidup wanita bekerja menunjukkan bahwa wanita yang bekerja memiliki tingkat kepuasan hidup sedikit lebih tinggi dibandingkan dengan wanita yang tidak bekerja, meskipun ada beberapa faktor lain yang ikut menentukan. Selain itu, hasil penelitian yang dimuat dalam Journal of Marriage and the Family tentang ukuran kebahagiaan hidup wanita yang sudah menikah, ditinjau dari tiga kategori: wanita bekerja, wanita pernah bekerja, dan wanita yang belum pernah bekerja, disimpulkan bahwa bagi istri bekerja, kebahagiaan perkawinan tetap menjadi prioritas utama dibandingkan dengan kepuasan kerja. Ini berarti, meskipun aktualisasi diri telah mendorong para perempuan untuk bekerja di luar rumah, tapi tidak menyurutkan keinginan mereka untuk menempatkan kebahagiaan keluarga sebagai hal yang paling utama.

\section{Dampak Wanita Karier bagi Keluarga}

Ketika perempuan memilih berkarier, sementara suaminya juga bekerja, maka timbul berbagai persoalan. Persoalan yang muncul dalam kondisi seperti ini dapat menentukan tingkat keberhasilan dual-career marriage. Misalnya, Suami yang merasa terancam, tersaingi, dan "cemburu" dengan status bekerja istrinya, biasanya tidak bersikap toleran terhadap. Ada pula suami yang tidak 
menganggap pekerjaan istri sebagai sebuah masalah, selama istrinya tetap dapat memenuhi dan melayani kebutuhan si suami. Barangkali ada pula suami yang justru mendukung karier istrinya dan turut serta mengurusi pekerjaan rumah tangga sehari-hari. Dalam kondisi yang terakhir, umumnya sang istri akan lebih merasa puas dan bahagia dalam hidup, keluarga, maupun kariernya. ${ }^{15}$ Sampai di sini, terlihat jelas bahwa keputusan wanita untuk bekerja di luar rumah bisa memunculkan berbagai persoalan, termasuk merubah konstruksi keluarga yang sudah terbangun.

Selain itu, munculnya persoalan dalam perkawinan akibat wanita bekerja tidak hanya terkait dengan suami atau keluarga seperti anak-anak, melainkan juga terkait dengan istri. Wanita yang bekerja di luar rumah akan terbentur berbagai masalah, mulai dari bagaimana mengatur waktu dengan suami dan anak hingga mengurus tugas-tugas rumah tangga dengan baik. Dalam konteks ini, ada istri yang bisa menikmati peran gandanya, namun ada juga yang merasa kesulitan menghadapinya hingga muncul persoalanpersoalan rumit yang kian berkembang dalam hidup seharihari.

Di sisi lain, persoalan-persoalan yang kerapkali muncul dan menghinggapi wanita karier bisa di dorong oleh berbagai faktor, yaitu:

\section{a) Faktor Internal}

Faktor internal berhubungan dengan persoalan yang timbul dalam diri pribadi wanita tersebut. Misalnya, wanita lebih suka menjadi ibu rumah tangga, di tuntut bekerja untuk menyokong keuangan keluarga. Kondisi tersebut mudah menimbulkan stress karena bekerja tidak timbul dari keinginan diri, tapi muncul

15 Journal of Marriage and the Family lihat juga http://www.ibubekerja.info/tag/ibu-bekerja. Akses tanggal 25 Maret 2012.

Sangaji Jurnal Pemikiran Syariah dan Hukum 
dari keterpaksaan karena tidak punya pilihan lain selain membantu ekonomi keluarga. Secara psikologis, wanita yang demikian akan merasa sangat lelah (terutama secara psikis), karena seharian "memaksakan diri" untuk bertahan di tempat kerja.

Persoalan pelik lain yang juga dihadapi wanita bekerja semacam ini adalah pada soal kemampuan "manajemen waktu dan rumah tangga". Mereka harus dapat memainkan peran mereka sebaik mungkin baik di tempat kerja maupun di rumah. Mereka harus siap menjadi ibu yang sabar dan bijaksana untuk anak-anak, menjadi istri yang baik bagi suami, sekaligus menjadi ibu rumah tangga yang bertanggung jawab atas keperluan dan urusan rumah tangga. Di sisi lain, di tempat kerja, mereka harus berkomitmen dan bertanggung jawab atas pekerjaan yang dipercayakan kepadanya hingga mampu menunjukkan prestasi kerja yang baik.

Pada tahap-tahap tertentu, "beban ganda" yang di tanggung wanita karier bisa menyeret kehidupan perkawinan pada persoalan kompleks, meski ada beberapa wanita yang tetap berpikiran ideal dapat mengatasi persoalan itu. Misalnya, ketika pekerjaan di kantor sangat berat, suami di rumah kurang bisa "bekerja sama" dalam menyelesaikan pekerjaan rumah, sementara anak-anak juga menuntut perhatian dirinya, sang ibu akan merasa sangat lelah karena dirinya merasa dituntut untuk terus memberi dan memenuhi kebutuhan orang lain. Belum lagi, jika ternyata suami dan anakanak merasa "kurang mendapat perhatian." Persoalanpersoalan ini bisa membawa perempuan pada kondisi depresi, karena merasa tidak bisa membahagiakan keluarganya. 


\section{b) Faktor Eksternal}

1) Dukungan suami

Istri yang bekerja mutlak membutuhkan dukungan dari suami, yakni sikap penuh pengertian suami yang ditunjukkan dalam bentuk kerja sama yang positif, ikut membantu menyelesaikan pekerjaan rumah tangga, membantu mengurus anakanak, serta memberikan dukungan moral dan emosional terhadap istrinya terkait pekerjaannya tersebut. Tapi, persoalannya, di Indonesia, iklim paternalistik dan otoritarian masih begitu kuat, sehingga ketika istri bekerja, suami seringkali tidak memberikan support, justru turut membebani peran ibu bekerja. Banyak hal yang menyebabkan suami tidak mendukung karier istrinya. Salah satunya terkait dengan pemahaman bahwa pria tidak boleh mengerjakan pekerjaan wanita, apalagi ikut mengurus masalah rumah tangga. Masalah rumah tangga sepenuhnya kewajiban seorang istri, yang segala akibatnya harus ditanggung oleh istri.

Pada tahap selanjutnya, ketiadaan dukungan suami berakibat pada besarnya tekanan pada pihak istri. Istri, selain akan menemui kesulitan karena tidak memiliki kebahagiaan dalam bekerja, perannya dalam keluarga pun tidak akan maksimal. Jika dibiarkan akan muncul ekses-ekses negatif lain bagi istri seperti, timbul rasa bersalah karena merasa diri bukan ibu dan istri yang baik.

2) Kehadiran anak

Masalah pengasuhan terhadap anak, biasanya dialami oleh para ibu bekerja yang mempunyai anak kecil/balita/batita. Semakin kecil usia anak, maka semakin besar tingkat stress yang dirasakan. Masalah 
akan muncul ketika istri merasa bersalah karena meninggalkan anak untuk seharian bekerja. Terlebih lagi bila pengasuh yang ada tidak dapat diandalkan, sementara tidak ada anggota keluarga lain yang dapat membantu.

3) Masalah pekerjaan

Pekerjaan bisa menjadi sumber ketegangan dan stress yang besar bagi para ibu bekerja. Persoalan-persolan seperti peraturan kerja yang kaku, bos yang tidak bijaksana, beban kerja yang berat, ketidakadilan di tempat kerja, rekan-rekan yang sulit bekerja sama, waktu kerja yang lama, adalah sebagian dari persoalan yang bisa menyebabkan ketidaknyamanan psikologis. Situasi ini bisa membuat wanita karier amat lelah, sementara kehadirannya masih sangat dinantikan oleh keluarga di rumah. Kelelahan psikis dan fisik inilah yang kerap kali membuat mereka sensitif dan emosional, baik terhadap anak-anak maupun terhadap suami. Keadaan ini biasanya makin parah ketika situasi di rumah tidak mendukung seperti situasi di mana suami dan anak-anak kurang bisa bekerja sama, termasuk mau melayani dan membantu sang ibu, atau sekedar meringankan pekerjaan rumah tangga.

4) Faktor Relasional

Bekerjanya suami dan istri secara bersamaan berkonsekuensi pada waktu untuk keluarga menjadi terbagi. Memang, penanganan terhadap pekerjaan rumah tangga bisa diselesaikan dengan disediakannya pengasuh serta pembantu rumah tangga. Tapi, tak bisa dipungkiri bahwa ada hal-hal yang sulit dicari penggantinya, seperti soal kebersamaan bersama suami dan anak-anak. 
Padahal, kebersamaan dalam suasana rileks, santai dan hangat adalah aktivitas penting dalam rangka membina, mempertahankan dan menjaga kedekatan relasi serta keterbukaan komunikasi satu sama lain. Bagi istri, kurangnya waktu untuk keluarga ini seringkali berujung pada perasaan bahwa dirinya tidak bisa berbicara secara terbuka dengan suaminya, bertukar pikiran, mencurahkan pikiran dan perasaan, atau merasa suaminya tidak lagi bisa mengerti dirinya. Hasilnya, ia merasa terasing dengan pasangan sendiri sehingga mulai mencari orang lain yang dianggap lebih bisa mengerti, dan sebagainya. Ini lah yang bisa membuka peluang terhadap perselingkuhan di tempat kerja.

Sampai di sini tampak bahwa wanita karier bisa memunculkan berbagai persoalan serius dalam perkawinan. Meski demikian, tidak berarti wanita karier selalu berkonotasi negatif. Ada beberapa manfaat positif baik bagi sang ibu bekerja maupun bagi keluarga ketika wanita karier, di antaranya: Pertama, mendukung ekonomi rumah tangga. Artinya, pekerjaan istri menjadikan sumber pemasukan keluarga tidak hanya satu, melainkan dua. Dalam situasi ini, pasangan tersebut dapat mengupayakan kualitas hidup yang lebih baik untuk keluarga dalam berbagai hal, seperti gizi, pendidikan, tempat tinggal, sandang, liburan dan hiburan, serta fasilitas kesehatan.

Kedua, meningkatkan harga diri, memantapkan identitas, dan menumbuhkan kepercayaan diri. Hal ini muncul dari konstruksi wanita bekerja yang memungkinkan seorang wanita bisa mengekspresikan dirinya sendiri secara kreatif dan produktif, membanggakan dirinya, terutama ketika prestasinya kerjanya mendapat penghargaan atau 
umpan balik yang positif. Dari sini, wanita bekerja berusaha menemukan arti dan identitas dirinya, hingga ia mampu mendatangkan rasa percaya diri dan kebahagiaan.

Ketiga, membangun relasi yang sehat dan positif dengan keluarga. Wanita yang bekerja, cenderung mempunyai ruang lingkup yang lebih luas dan bervariasi, sehingga cenderung mempunyai pola pikir yang lebih terbuka, energik, luas dan lebih dinamis. Karena itu, keberadaan istri bisa menjadi partner bagi suami, untuk menjadi teman bertukar pikiran, serta saling membagi harapan, pandangan dan tanggung jawab.

Keempat, memenuhi kebutuhan sosial. Hal ini terkait dengan setiap manusia, termasuk para ibu, mempunyai kebutuhan untuk menjalin relasi sosial dengan orang lain. Dengan bekerja, seorang wanita juga dapat memenuhi kebutuhan itu dan bisa menjadi bagian dari suatu komunitas. Selain itu, bekerja menjadi sarana sosialisasi diri bagi istri untuk dapat menjadi tempat pengalihan energi secara positif, barangkali dari berbagai masalah yang menimbulkan tekanan, baik menyangkut masalah yang sedang dialami dengan suami, anak-anak maupun dalam pekerjaan. Dengan sejenak bertemu dengan rekan-rekan, mereka dapat saling berbagi perasaan, pandangan dan bahkan berbagi solusi.

Kelima, meningkatkan skill dan kompetensi. Dengan bekerja, seorang wanita harus bisa menyesuaikan diri dengan tuntutan, baik tuntutan tanggung jawab maupun skill dan kompetensi. Dalam hal ini, seorang wanita dituntut untuk secara kreatif menemukan segi-segi yang bisa dikembangkan demi kemajuan dirinya. Peningkatan skill dan kompetensi yang terus menerus akan mendatangkan "nilai lebih" pada dirinya sebagai seorang karyawan, selain rasa percaya diri yang mantap. 


\section{Beberapa Fakta tentang Wanita Bekerja}

Di atas telah diungkap bagaimana konstruksi keluarga yang terbangun ketika sang ibu bekerja di luar rumah. Untuk lebih memperkaya wacana, kita perlu melihat beberapa fakta yang terungkap dari hasil penelitian menyangkut situasi-situasi keluarga, di mana keduanya (suami dan istri) sama-sama bekerja. Isu yang diangkat bermacam-macam, mulai dari kepuasan hidup, kebahagiaan perkawinan, hingga dukungan suami.

Dalam studinya tentang kepuasan hidup wanita bekerja yang pernah, Ferree (1976) menunjukkan bahwa wanita memiliki tingkat kepuasan hidup sedikit lebih tinggi dibandingkan dengan wanita yang tidak bekerja, meski ada beberapa faktor lain yang ikut menentukan.

Freudiger, P. (1983), sebagaimana termuat dalam Journal of Marriage and the Family, 45, 213 - 219 - meneliti ukuran kebahagiaan hidup wanita yang sudah menikah, yang kemudian ia ditinjau dari 3 kategori: wanita bekerja, wanita pernah bekerja dan wanita yang belum pernah bekerja, menyimpulkan bahwa bagi para istri dan ibu bekerja, kebahagiaan perkawinan adalah tetap menjadi prioritas utama, dibandingkan dengan kepuasan kerja. Sementara itu, Walters dan McKenry (1985), dalam penelitiannya tentang kebahagiaan ibu bekerja menyimpulkan bahwa wanita bekerja cenderung merasa bahagia selama dapat mengintegrasikan kehidupan keluarga dan kehidupan kerja secara harmonis. Ketika hal ini tak terjadi, justeru konflik peran dialami oleh ibu bekerja, maka kepuasan hidup wanita bekerja menjadi terhambat. Perasaan bersalah karena meninggalkan perannya sementara waktu sebagai ibu rumah tangga, bisa membuat ibu tersebut tidak dapat menikmati perannya dalam dunia kerja.

Sangaji Jurnal Pemikiran Syariah dan Hukum 
Di sisi lain, dukungan suami adalah salah satu faktor penting bagi perempuan yang bekerja. Hal ini dibuktikan oleh Jones dan Jones (1980). Dari hasil penelitiannya terungkap bahwa sikap suami merupakan faktor yang penting dalam menentukan keberhasilan dual-career marriage. Suami yang merasa terancam, tersaingi dan cemburu dengan status "bekerja" istrinya, tidak bisa bersikap toleran terhadap keberadaan istri yang bekerja. Ada pula suami yang tidak menganggap pekerjaan istri menjadi masalah, selama istrinya tetap dapat memenuhi dan melayani kebutuhan suami. Namun ada pula suami yang justru mendukung karier istrinya, dan ikut bekerja sama dalam mengurusi pekerjaan rumah tangga sehari-hari. Dalam kondisi terakhir ini, umumnya istri akan lebih merasa puas dan bahagia.

Terakhir, dalam sebuah penelitian yang dilakukan oleh Scanzoni (1980) terungkap bahwa perkawinan dualcareer dikatakan berhasil jika di antara kedua belah pihak (suami dan istri) saling memperlakukan pasangannya sebagai partner yang setara. Pada umumnya, mereka tidak hanya akan berbagi dalam hal income, namun tidak segansegan berbagi dalam urusan rumah tangga dan mengurus anak.

Dari fakta-fakta yang terungkap tersebut, bisa dikatakan bahwa ketika kebahagiaan perkawinan terkait dengan istri yang bekerja bisa terwujud manakala masingmasing anggota keluarga saling toleran dan mendukung satu sama lain, keluarga di bangun atas dasar egaliter dengan pola partnership, serta kepentingan keluarga tetap ditempatkan sebagai prioritas yang utama. 


\section{Beberapa Solusi}

Sebagaimana telah disinggung di atas, dalam keluarga dimana wanita karier tidaklah sederhana. Banyak persoalan muncul. Karena itu, diperlukan penanganan tepat, sehingga wanita karier tidak berefek negatif bagi kelangsungan perkawinan dan keluarga, melainkan bisa berkonstribusi positif bagi semua pihak. Ada beberap solusi yang patut dipertimbangkan ketika perempuan berkerja, yaitu:

Pertama, manajemen waktu, yakni strategi penting yang perlu diterapkan oleh ibu bekerja untuk mengoptimalkan perannya sebagai ibu rumah tangga, istri dan sekaligus karyawati. Hal ini bisa dilakukan dengan berbagai cara, yaitu: (1) menentukan tujuan yang jelas bagi perempuan yang hendak bekerja. (2) menetapkan prioritas untuk masing-masing peran (sebagai istri, ibu atau karyawan). Hal ini bisa dilakukan misalnya dengan menetapkan jadwal kegiatan dari pagi hingga malam, sambil memberi fokus pada hal-hal tertentu yang dianggap priortas. Hal yang sederhana seperti, sepulang kerja istri menyediakan waktu untuk anak maupun suami. Intinya, istri sebaiknya dapat mengatur kegiatan secara lebih sistematis dan efisien. (3) Mendelegasikan beberapa tugas (baik tugas kantor maupun tugas rumah) kepada orang lain agar dapat meluangkan lebih banyak waktu untuk keluarga. Pendelegasian pekerjaan, membuat Anda akan merasa lebih rileks dan dapat memfokuskan diri pada pekerjaan yang betul-betul harus Anda sendiri yang mengerjakan. Pendelegasian bisa berupa pelimpahan pengurusan rumah tangga kepada pembantu rumah tangga, pengurusan anak pada orang tua, dan sebagainya.

Kedua, manajemen keluarga. Hal ini bisa dilakukan dengan mengatur peran yang di emban sang istri. 
Sebagaimana tampak di atas, peran ganda istri membutuhkan komitmen yang tinggi baik sebagai karyawan maupun sebagai ibu. Dalam meringankan beban itu, keluarga bisa mempekerjakan pembantu rumah tangga. Bagi pasangan yang mempunyai anak relatif lebih besar, dapat ditanamkan pengertian pada mereka untuk ikut membantu mengelola tugas rumah tangga sehari-hari. Ajarkan prinsip kerja sama dan tanggung jawab sejak dini pada anak, agar ia terbiasa bersikap mandiri, berinisiatif dan dapat diandalkan. Jika anak masih kecil, upayakan untuk menyediakan pengasuh yang baik, bertanggung jawab dan dapat dipercaya.

Ketiga, manajemen pekerjaan. Hal ini terkait dengan upaya membangun quality time bersama keluarga. Untuk menyediakan waktu lebih banyak bersama keluarga diperlukan efisiensi dan produktivitas dalam pekerjaan. Keempat, manajemen diri, yakni mengatur diri sendiri dalam hal membangun sikap toleransi, menghindarkan tindakantindakan dan pikiran-pikiran negatif, serta mengatur waktu untuk memenuhi kepentingan diri sendiri.

Kelima, memelihara dukungan sosial. Artinya, perempuan yang bekerja harus mampu memelihara hubungan baik dengan rekan-rekan di sekelilingnya. Hal ini perlu dilakukan untuk mencegah timbulnya masalah yang tidak diinginkan, selain untuk mendapatkan dukungan moril dan emosional dari rekan-rekan atau atasan. Bila hal ini bisa dilakukan, wanita karier akan lebih rileks, termasuk dapat membagi beban pekerjaan pada sesama rekan. ${ }^{16}$

16Jacinta F. Rini, Wanita Bekerja, Team e-psikologi, Jakarta, 28 Mei 2002 lihat http://denmasgoesyono.multiply.com. Akses tanggal 25 Maret 2012. 


\section{Wanita Karier dalam Perspektuif Islam}

Peradaban Islam lahir dan bersumber pada teks. Karena itu, semua diskursus dalam Islam tidak bisa dilepaskan dari teks, terutama al-Qur'an dan al-Hadits. Begitu pula dengan masalah wanita karier, ia tidak bisa dilepaskan dari berbagai konsepsi Islam tentang relasi laki-laki dan perempuan, yang juga didasarkan pada teks. Karena itu, ketika hendak menjawab apakah wanita boleh bekerja di luar rumah atau tidak, kita bisa merujuk pada berbagai konseps Islam tentang laki-laki dan perempuan yang juga dilandaskan pada teks. Berikut akan diurai beberapa konsep Islam yang memuat relasi laki-laki dan perempuan dan hubungannya dengan wanita karier.

1. Kepemimpinan Keluarga Egaliter dan Wanita Karier

Konsep kepemimpinan dalam rumah tangga menjadi salah satu isu penting dalam wacana gender. Selain merupakan tema yang hingga kini masih diperdebatkan, konsep kepemimpinan rumah tangga juga sering dijadikan pijakan bagi pola hubungan antara suami dan istri. Sebagian feminis muslim menggugat faham kemutlakan kepemimpinan suami dalam rumahtangga, karena dinilai bertentangan dengan konsep kesetaraan pria dan wanita. Konsep kepemimpinan dalam rumah tangga sendiri menjadi kontroversial ketika terdapat pemahaman terhadap firman Allah Swt. dalam Surat An-Nisa' (4):4:34, yang artinya:

"Kaum laki-laki adalah pemimpin bagi kaum perempuan, oleh karena Allah telah melebihkan sebagian mereka (lakilaki) atas sebagian yang lain (wanita) dan karena mereka telah menafkahkan sebagian dari harta mereka."

Bagi pemikir normatif ayat tersebut berbicara tentang superioritas laki-laki atas perempuan dengan menempatkan laki-laki sebagai pemimpin rumah tangga dan perempuan sebagai pihak yang dipimpin. Kesimpulan ini di dasarkan 
pada lafaz qawwamun yang diartikan pemimpin serta potongan ayat bima faddalallah $b a^{\prime} d u h u m$ ala $b a^{\prime} d i n$ dan wabima anfaqu min amwalihim. Dari sini ditemukan dua poin penting, yaitu: pertama, laki-laki secara potensial memiliki kelebihan atas perempuan. Kedua, dengan kelebihannya, laki-laki mempunyai hak dan tanggung jawab atas kehidupan keluarganya, istri, dan anak. ${ }^{17}$ Konekuensinya, istri, mau tidak mau, harus taat pada suami, termasuk dalam hal pekerjaan. Seumpama suaminya melarangnya bekerja, maka ia harus menaatinya.

Persoalannya sekarang apakah benar laki-laki pemimpin bagi perempuan dan harus ditaati secara mutlak? Tampaknya, pemahaman yang mengatakan bahwa suami memiliki peran mutlak sebagai pemimpin bagi wanita, karenanya wanita harus menaatinya, cenderung mengabaikan konteks historis ayat. Padahal, ayat itu seharusnya dipahami secara kontekstual. Surat al-Nisa' :4:34

17 Tokoh yang termasuk kelompok normatif misalnya Muhammad Ali ash-Shabuni dan Imam Baidhawi. Menurut ash-Shabuni, qawwamu>n berarti pemimpin karena dua alasan, pertama, laki-laki memiliki kelebihan akal dibanding perempuan. Kedua, laki-laki yang memberi nafkah keluarganya. Konsekuensinya, perempuan harus taat kepada Allah dan suaminya, baik di rumah maupun di luar rumah. Jika isteri nusyuz, maka suami berhak memberikan teguran dan pengarahan bahkan pukulan demi mendidik isteri dan menjaga nama baik keluarga. Menurut ash-Shabuni, kedudukan suami bagi isterinya sama dengan kedudukan pemimpin bagi rakyatnya. Sementara bagi Baidhawi, laki-laki menjadi karena, pertama, laki-laki memiliki kelebihan khusus dari Allah (kelebihan tanpa usaha) berupa kelebihan akal pikiran. Kedua, kelebihan yang diusahakan (kasbi), yaitu laki-laki diposisikan sebagai pihak yang bertanggung jawab atas kehidupan rumah tangga. Oleh karena itu, seorang isteri harus taat kepada Allah dan menegakkan hak-hak suaminya. Bagi Baidhowi, suami pada gilirannya berhak mendidik isterinya dan mencegahnya keluar rumah, berhak atas seluruh hartanya dan isteri tidak bisa membelanjakan harta tersebut tanpa izin suaminya, serta kewajiban menafkahi isterinya.Aksin Wijaya, Menggugat Otentisitas Wahyu Tuhan:Kritik Atas Nalar Tafsir Gender, (Yogyakarta: Safiria Insania Press, 2004), hlm. 176. 
adalah ayat kontekstual, yang karenanya tidak bisa dipahami lepas dari konteks sosial pada waktu ayat itu diturunkan. ${ }^{18}$ Dari pembacaan kontekstual didapatkan bahwa keunggulan pria bukanlah keunggulan jenis kelamin, tetapi keunggulan fungsional, karena pria mencari nafkah dan membelanjakan hartanya untuk wanita (istri). Fungsi sosial yang di emban pria seimbang dengan wanita yang melaksanakan tugas-tugas domestik dalam rumahtangga. Karena itu, ungkapan "Kaum laki-laki adalah pemimpin bagi kaum perempuan" bukanlah pernyataan normatif tetapi kontekstual.

Selain itu, makna "qawwamun" dalam ayat tersebut sebenarnya tidak harus bermakna pemimpin, melainkan bisa juga penopang atau penguat bagi istri, sehingga lakilaki bukanlah sosok penguasa yang bersifat menguasai dan mendominasi, melainkan sebagai pendukung bagi pasangannya. karena itu, menempatkan perempuan di bawah dominasi laki-laki dalam segala urusan merupakan pendirian kelelakian yang melampaui batas. ${ }^{19}$ Dan yang lebih penting lagi, ayat tersebut tidak menentukan relasi laki-laki dan perempuan secara absolut dan tidak bergantung. Sebaliknya, status laki-laki maupun perempuan bergantung pada tindakan manusia "sesuai dengan kekayaan yang dinafkahkan untuk yang lain" dan bergantung pada tindakan Tuhan (yaitu, dengan kelebihan yang dianugerahkan Tuhan pada seseorang di atas yang lain). Hal ini selaras dengan ayat lain yang menunjukan bahwa fadl keutamaa), baik yang berkaitan dengan pahala atau anugerah Tuhan, bisa diperoleh oleh siapa pun.

18 Asghar Ali Engineer, Hak-hak Perempuan dalam Islam, alih bahasa oleh Wajdi dan Cici Farkha Assegaf (Yogyakarta: Yayasan Bintang Budaya, 1994), h. 61.

${ }^{19}$ Masdar F. Mas'udi, Islam dan Hak-hak Reproduksi Perempuan, hlm.67-68.

Sangaji Jurnal Pemikiran Syariah dan Hukum 
Otoritas yang diberikan kepada laki-laki bukan karena dia laki-laki, tapi karena waktu itu, laki-laki yang menafkahi perempuan. Namun, apabila perempuan memiliki tanggung jawab yang sama dengan laki-laki, otoritas harus dibagi secara adil di antara keduanya. ${ }^{20}$ Sampai di sini tampak bahwa dalam ayat tersebut juga mengandung nilai keadilan dalam hal pemberian posisi bagi pihak-pihak yang mempunyai peran lebih dalam keluarga.

Dari pembacaan di atas bisa didapatkan bahwa Islam tidak menilai laki-laki lebih tinggi dari perempuan. Keduanya adalah setara dan seharusnya saling mendukung dan melengkapi. Islam juga menuntut diaplikasikannya nilai-nilai keadilan bagi suami dan istri. Karena itu, dalam konteks wanita karier, tidak boleh ada diskriminasi dalam memberikan kesempatan memperoleh pendidikan, agar dalam mengarungi kehidupannya, wanita dapat serasi mengimbangi pria terutama pasangan hidupnya. Dengan pendidikan itu, wanita diharapkan dapat memperoleh pekerjaan yang layak sesuai dengan kemampuan dan kodratnya, sehingga hidupnya produktif, tidak stress atau menjadi penghayal karena terlalu banyak waktu luang yang ia lalui, yang tidak mustahil berujung pada kejenuhan dan melahirkan sikap-sikap negatif yang merugikan orangorang yang ada di sekitarnya. Sehingga bisa dipahami bila al-Hatimi menyatakan bahwa wanita boleh bekerja dan menduduki jabatan strategis di wilayah publik dengan catatan tetap tunduk pada ajaran syari at, serta tetap memprioritaskan peran utamanya sebagai ibu rumah tangga. Hal ini didasarkan pada fakta historis bahwa wanita

${ }^{20}$ Khaled M. Abou el-Fadl, Selamatkan Islam dari Muslim Puritan, alih bahasa oleh Helmi Mustofa, (Jakarta: Serambi, 2006), hlm. 320-321. 
di zaman Nabi Saw. ikut berpartisipasi dalam urusan publik, seperti dalam peperangan. ${ }^{21}$

\section{Wanita Karier dan Kesetaraan Gender}

Islam adalah agama yang membawa nilai-nilai kesetaraan gender. Dalam ayat-ayat al-Qur'an ditegaskan bahwa laki-laki dan perempuan mempunyai tanggung jawab yang sama di hari pembalasan. ${ }^{22}$ Laki-laki dan perempuan diciptakan dari jenis yang sama (nafsin wahidah). ${ }^{23}$ Kemuliaan laki-laki dan perempuan sama di lihat dari prestasinya. ${ }^{24}$ Serta sebagai suami dan istri, laki-laki dan perempuan mempunyai kedudukan yang sederajat..$^{25}$ Artinya, laki-laki dan perempuan sama-sama sebagai hamba, sama-sama sebagai khalifah di bumi, sama-sama menerima perjanjian primordial, adam dan hawa samasama terlibat secara aktif dalam drama kosmos, serta lakilaki dan perempuan sama-sama berpotensi untuk meraih prestasi. ${ }^{26}$ Lebih tegas lagi misalnya, Khoiruddin Nasution menghimpun sejumlah nash yang berbicara tentang kemitrasejajaran perempuan dan laki-laki yang dapat dikelompokkan menjadi delapan, ${ }^{27}$ yakni: (1) statmen umum tentang kesetaraan perempuan dan laki-laki, ${ }^{28}(2)$ kesetaraan

${ }^{21}$ Moenawar Khalil, Nilai Wanita, ( Solo: Ramadhani, 1989), hlm. 81.

${ }^{22}$ Al-An'am [6] : 164, ayat yang senada al-Mu'min [40] : 17, al-Muddassir [74] : 78

${ }^{23}$ An-Nisa' [4] : 1.

${ }^{24}$ Ali 'Imran [3] : 195, ayat yang senada an-Nahl [16] : 97, al-Hujurat [49]: 14.

${ }^{25}$ An-Nisa' [4] : 32, ayat yang senada an-Nisa' [4] : 35 .

26 Nasarudin Umar Argumen Kesetaraan Gender: Perspektif Al-Qur'an (Jakarta : Paramadina, 1999), hlm. 247-265.

27 Khoiruddin Nasution, Fazlur Rahman tentang Wanita (Yogyakarta: Tazzafa \& ACAdeMIA, 2002), hlm. 22.

${ }^{28}$ Al-Baqarah [2] : 187, 228.

Sangaji Jurnal Pemikiran Syariah dan Hukum 
asal usul, $^{29}$ (3) kesetaraan amal dan ganjarannya, ${ }^{30}$ (4) kesejajaran untuk saling kasih dan mencintai, ${ }^{31}$ (5) keadilan dan persamaan, ${ }^{32}$ (6) kesejajaran dalam jaminan sosial, ${ }^{33}$ (7) saling tolong-menolong, ${ }^{34}$ (8) kesejajaran dalm hal kesempatan mendapat pendidikan. ${ }^{35}$

Al-Qur'an sendiri mengatakan bahwa pahala setiap orang yang beramal-laki-laki maupun perempuan, besar kecil, tua muda-sepanjang dirinya cakap hukum (memenuhi persyaratan syar'i), maka ia berhak mendapatkan pahala dari hasil perbuatannya. Artinya, tidak ada pembedaan reward yang akan diterima oleh seorang pelaku kebajikan hanya karena perbedaan jenis kelamin ataupun umur. Sebagaimana diterangkan dalam Al-Qur'an surat An-Nahl(16): 97:

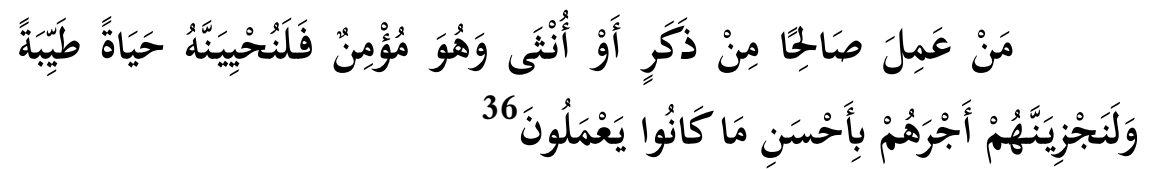

Terjemahnya::

"Barangsiapa yang mengerjakan amal saleh, baik laki-laki maupun perempuan dalam keadaan beriman, maka sesungguhnya akan Kami berikan kepadanya kehidupan yang baik dan

${ }^{29}$ An-Nisa' [4] : 1, Al-Hujurat (49) : 13.

${ }^{30}$ Ali 'Imran [3] : 195, an-Nisa' [4] : 32, at-Taubah [9] : 72, al-Ahzab [33] : 35-36, al-Mu'min [40] : 40, al-Fath [48] : 5, al-Hujurat [49] : 13, al-Hadid [57] : 12, dan al-Mumtahanah [60] : 12.

${ }^{31}$ Al-Isra' [17] : 24, ar-Rum [30] : 21, al-Ahqaf [46] : 15 dan Al-Baqarah [2]: 187.

\footnotetext{
32 Al-Baqarah [2] : 228 dan an-Nahl [67] : 97.

33 Al-Baqarah [2] : 177.

${ }^{34}$ At-Taubah [9] : 71, al-Maidah [5] : 2.

35 Al-Mujadalah [58] : 11, Az-Zumar [39] : 9.

36 An-Nahl (16): 97.
} 
sesungguhnya akan Kami beri balasan kepada mereka dengan pahala yang lebih baik dari apa yang telah mereka kerjakan."

Dari ayat di atas serta berbagai ayat Al-Qur'an yang menjelaskan ajaran persamaan laki-laki dan perempuan dalam Islam, bisa di tarik benang merah bahwa laki-laki dan perempuan memiliki hak dan kewajiban yang sama, termasuk dalam hal bekerja. tidak ada diskriminasi bagi wanita dalam hal meniti karier. Pembedaan hanya terletak pada jenis pekerjaan yang akan dibedakan menurut kredibilitas, skill dan kompetensi masing-masing. Artinya, pembedaan hanya terletak pada peran yang bersifat kodrati. Tentu, hamil dan menyusui merupakan tanggung jawab istri, bukan suami, karena ia bersifat kodrati.

Bukti bahwa tidak ada pembedaan antara laki-laki dan perempuan dalam bekerja adalah kisah hidup salah satu ummahat umat Islam, yakni, Khadijah binti Khuwailid Ra. Khadijah adalah sosok manusia yang gigih dan mampu mengantarkan kesuksesan Nabi Muhammad Saw. Tentunya sedikit banyak harta Khadijah didermakan untuk kepentingan umat saat itu. Segala keperluan peperangan Nabi selalu dilayani oleh Khadijah. Dan hal semacam ini tidak dilarang oleh Nabi. Karena itu, aneh bila kini wanita karier dipersoalkan sedangkan telah jelas Khadijah pun juga berdagang dan berbisnis. Padahal Nabi sendiri tidak melarangnya. Selain itu, Al-Qur'an tidak mencegah perempuan ke luar rumah dan juga tidak menyebutkan bahwa mereka harus ditemani oleh keluarga dekat laki-laki ketika mereka bepergian ke luar rumah. Pada masa Nabi juga perempuan berpartisipasi dalam peperangan yang secara ketat merupakan wilayah yang didominasi oleh lakilaki. Diriwayatkan dalam Sahih Bukhari, bahwa perempuan muslim secara aktif membantu mereka yang terluka di saat 
perang Uhud berkecamuk. Termasuk di dalam perempuan ini adalah istri nabi sendiri. ${ }^{37}$

Secara umum, Islam sangat menghormati kewajiban wanita yang sangat sesuai dengan fitrah kewanitaannya. Sebagaimana disinggung di atas, wanita mempunyai kesempatan bekerja di sektor luar rumah, namun pekerjaannya juga harus sesuai dengan kodrat kewanitannya. Islam tidak memperbolehkan wanita bekerja dan atas pekerjaannya itu menjadikannya terhina. Wanita bisa bekerja di luar rumah, selama pekerjaan itu sesuai dengan tabi'at, spesialisasi dan kemampuannya, serta tidak merusak derajat kewanitannya. Oleh karenanya, Islam mensyariatkan pula bagi wanita untuk bekerja di luar rumahnya, atau pada saat masyarakat iru sendiri sangat membutuhkan pekerjaannya. Dan kebutuhan untuk bekerja di sini bukan hanya kebutuhan yang terbatas pada penghasilan materi saja, namun juga terkadang telah menjadi kebutuhan psikisnya, seperti kebutuhan guru wanita yang belum kawin dalam bidang-bidang tertentu, atau guru wanita yang sudah kawin namun belum memiliki keturunan, atau adanya perasaan hampa yang berlarut-larut atau adanya perasaan bosan yang dapat menjadikan stress. ${ }^{38}$

${ }^{37}$ Kitab Fath Khaibar karya Abu Daud menyatakan bahwa ketika perang Kahibar terjadi, setengah lusin perempuan Madinah ikut tentara Islam. Nabi tidak mengetahui hal tersebut, dan ketika diberitahu nabi pun marah dan berkata : "Mengapa mereka ikut?" para wanita ini kemudian menimpali bahwa mereka membawa obat-obatan, mereka akan merawat pejuang Islam yang terluka, mencabut panah dari tubuh tentara, dan mengatur makanan mereka. Mendengar hal demikian, nabi pun mengijinkan mereka untuk menemni tentara, dan ketika Khaibar ditaklukkan, nabi juga membagi ghanimah kepada para wanita tersebut. Lihat Heroic Deeds of Muslim Women, Islamabad, 1990, hlm. 2-3.

38 Yusuf al-Qardhawi, Ruang Lingkup Aktivitas Wanita Muslimah, alih bahasa oleh Moh. Suri Sudahri dan Entin Rani'ah Ramelan, cet. Ke-1 (Jakarta: PUSTAKA KAUTSAR, 1996), hlm. 224. 
Karena itu, kebolehan wanita karier tidak berarti wanita bebas bekerja sebebas-bebasnya, melainkan ia juga harus memperhatikan kodrat kewanitaannya.

\section{Batasan Wanita Karier}

Dari uraian di atas, dapat dikatakan bahwa bahwa wanita karier dalam Islam diperbolehkan. Masalahnya, apakah semua jenis dan motif wanita yang hendak meniti karier di luar rumah diperbolehkan? Persoalan ini tidak mudah di jawab karena berbicara wanita karier kaitannya dengan perkawinan dan keluarga, tidak hanya soal bolehtidak boleh, lebih dari itu, ia menyangkut persoalan psikologis dan kepentingan dari masing-masing anggota keluarga, seperti istri, suami dan anak. Meski demikian, barangkali bisa disebut beberapa pendapat para sarjana Muslim sebagai pintu masuk untuk mengurai permasalahan.

Menurut Yusuf al-Qaradowi tidak ada larangan bagi wanita bekerja atau melakukan aktifitas di luar rumah untuk mengembangkan kariernya asal pekerjaan domestik tidak ditinggalkan, seperti memelihara rumah tangga, hamil, melahirkan, mendidik anak dan menjadi tempat berteduhnya suami guna mendapatkan ketenangan ketika suami datang dari kerja dan kelelahan setelah bersusah payah mencari nafkah. Bahkan wanita yang bekerja di luar rumah kadang-kadang di tuntut dengan ketentuan sunnah dan wajib apabila ia membutuhkannya, dengan catatan pekerjaan itu sesuai dengan tabi'at spesialisasi dan kemampuan serta tidak merusak derajat kewanitaannya, ${ }^{39}$ seperti bekerja untuk mengobati orang sakit, berniaga untuk keperluan keluarga, seperti yang dilakukan Khadijah istri

39 Yusuf al-Qaradawi, Fatwa-fatwa Kontemporer, alih bahasa oleh As'ad Yasin, (Jakarta: Gema Insani Press, 1996), hlm. 422.

Sangaji Jurnal Pemikiran Syariah dan Hukum 
Rasulullah. Selain itu, tidak ada larangan bagi wanita untuk bekerja dan berkarier apabila mampu, dan tetap mendapatkan nafkah dari suaminya karena nafkah merupakan beban finansial yang ditanggung oleh suami.

Sementara itu, Engineer mengatakan nafkah merupakan tanggung jawab suami kepada istrinya, meskipun istri memiliki kekayaan dan pendapatan. Nafkah kepada istri adalah konsekuensi adanya ikatan perkawinan yang sah. ${ }^{40}$ Dengan prinsip kemitra sejajaran antara suami istri yang digunakan oleh al- al-Qaradhawi, berarti tidak ada larangan bagi istri untuk membantu suami dalam mencari nafkah dengan izin suaminya, tidak menggangu pelaksanaan kewajibannya sebagai seorang ibu rumah tangga dan tidak mendatangkan suatu yang negatif dari diri sendiri, keluarga, masyarakat dan agamanya.

Merujuk pada fakta historis Islam, Quraish Shihab menegaskan bahwa tidak berlebihan jika dikatakan bahwa Islam membenarkan mereka aktif dalam berbagai aktifitas. Menurutnya, para wanita boleh bekerja dalam berbagai bidang, di dalam maupun di luar rumah, secara mandiri ataupun bersama orang lain, dengan lembaga pemerintah maupun swasta, selama pekerjaan tersebut dilakukan dalam suasana terhormat, sopan, serta selama mereka dapat memelihara agamanya, serta dapat pula menghindari dampak-dampak negatif dari pekerjaan tersebut terhadap diri dan lingkungannya. Singkatnya, wanita memiliki hak untuk bekerja dan berkarier selama pekerjaan tersebut membutuhkannya dan atau selama mereka membutuhkan pekerjaan tersebut. ${ }^{41}$

40 Ashar Ali Engineer, Hak-hak perempuan dalam Islam, alih bahasa oleh Farid wajidi, (Bandung: LSPPA, 1994), hlm. 164.

${ }^{41}$ M. Quraish Shihab, Membumikan Al-Qur'an:Fungsi dan Peran Wahyu dalam Kehidupan Masyarakat (Bandung: Mizan, 1994), hlm. 275 
Argumentasi berbeda diungkapkan seorang Kyai yang juga dikenal sebagai feminis, Husein Muhammad. Menurutnya, sesungguhnya Islam tidak pernah menekankan wanita dalam bidang pekerjaan, baik di dalam maupun di luar rumah. Islam memandang perempuan bukan sebagai mahluk domestik (mahluk rumahan) yang tidak diperkenankan merambah wilayah publik (umum). Pria dan wanita sama-sama berhak berkiprah di segala bidang, baik sosial, pendidikan, politik maupun lainya, termasuk di dalamnya hak untuk berkarier dalam bidang ekonomi. Pria dan wanita mempunya hak yang sama untuk bekerja, sekaligus menikmati hasil jerih payahnya.

Barangkali persoalan akan timbul ketika seorang istri yang bekerja itu tidak mendapat restu suaminya. Hal ini seringkali dianggap melanggar agama, karena dianggap menentang keputusan suami. Bagi Husein Muhammad, cara pandang seperti ini keliru dan tidak bisa serta merta di anggap melanggar agama. Harus di lihat terlebih dulu apa yang melatari suami tidak merestuinya. Sebab alasan suami tidak mengijinkan istri bekerja biasanya lebih karena alasan pribadi bukan karena alasan agama. Terlebih lagi, jika di simak lebih dalam, menurutnya, banyak ulama yang berpandangan bahwa suami tidak berhak untuk melarang istri bekerja mencari nafkah, apabila nyata-nyata suami tidak mampu bekerja mencari nafkah, baik karena sakit, miskin atau karena yang lain. Jadi kewajiaban seorang suami untuk mencari nafkah tidak menghalang istri untuk bekerja di luar rumah atau berkarier juga mencari nafkah.

\section{E. PENUTUP}

Dari uraian di atas, bisa disimpulkan, yaitu: pertama, secara psikologis, keberadaan wanita karier bisa mempengaruhi tatanan perkawinan dan keluarga, yang apabila 
tidak di atur dengan baik bukan mustahil akan berakibat pada disharmonisasi perkawinan dan keluarga. Kedua, dalam Islam tidak ada yang berhak melarang wanita untuk bekerja di luar rumah, termasuk suami sekalipun. Hal ini terkait dengan doktrin Islam sendiri yang sebenarnya tidak pernah membedakan antara laki-laki dan perempuan dari sisi jenis kelamin. Selain itu, Islam juga menghargai persamaan hak bagi laki-laki dan perempuan. Hal ini dipertegas oleh fakta historis pada masa Nabi, di mana wanita berparisipasi di sektor publik. Ketiga, wanita karier tidak berarti seorang istri/ibu bebas bekerja menelantarkan nasib perkawinan dan keluarganya. Artinya, pekerjaan yang diambil oleh wanita yang hendak meniti karier di sektor publik harus didasarkan pula atas kepentingan keluarga. 


\section{Daftar Pustaka}

Bauna'i, "Wanita Karier dalam Perspektif Hukum Islam," KARSA, Vol. 11, Mei 2001.

Dalam, Juwairiah, Peranan Wanita dalam Islam: Studi tentang Wanita karier dan Pendidikan Anak, Yogyakarta: Disertasi IAIN Sunan Kalijogo, Tidak diterbitkan, 2000.

Engineer, Asghar Ali, Hak-hak Perempuan dalam Islam, Terj. Wajdi dan Cici Farkha Assegaf Yogyakarta: Yayasan Bintang Budaya, 1994.

Engineer, Asghar Ali, Islam dan Teologi Pembebasan, alih bahasa oleh Agung prihantoro, cet.ke-1, Yogyakarta: Pustaka Pelajar, 1999.

Engineer, Asghar Ali, Hak-hak perempuan dalam Islam, alih bahasa Farid wajidi, Bandung: LSPPA, 1994.

Fadl, Khaled M. Abou el-, Selamatkan Islam dari Muslim Puritan, alih bahasa Helmi Mustofa, Jakarta: Serambi, 2006.

Fakih, Mansour, dkk., Membincang feminisme: Diskursus Gender Perspektif Islam, Surabaya: Risalah Gusti, 1996.

Fakih, Mansour. "Fiqh Sebagai Paradigma Keadilan," dalam Noor Ahmad, dkk., Epistemologi Syara': Mencari Format Baru Fiqh Indonesia, cet.ke-1, Yogyakarta: Pustaka Pelajar, 2000.

Heroic Deeds of Muslim Women, Islamabad, 1990, hlm. 2-3.

Ihromi, T.O. (Peny.), Kajia Wanita Dalam Pembangunan Jakarta, Jakarta: Yayasan Obor Indonesia, 1995.

Jacinta F. Rini, Wanita Bekerja, Team e-psikologi, Jakarta, 28 Mei 2002 lihat http://denmasgoesyono.multiply.com.

Journal of Marriage and the Family atau http://www.ibubekerja.info/tag/ibu-bekerja.

Khalil, Moenawar, Nilai Wanita, (Solo: Ramadhani, 1989.

Mas'udi, Masdar F. Islam dan Hak Reproduksi Perempuan, Bandung: Mizan, 1997.

Mernissi, Fatima. Wanita di dalam Islam, alih bahasa oleh Yaziar Radianti, Bandung: Pustaka, 1994.

Sangaji Jurnal Pemikiran Syariah dan Hukum 
Muleono, Anton M. Kamus Besar Bahasa Indonesia, cet. II, Jakarta: Departemen Pendidikan dan Kebudayaan, 1989.

Nasution, Khoiruddin, Fazlur Rahman tentang Wanita, Yogyakarta : Tazzafa \& ACAdeMIA, 2002.

Nurhadi, Toety Herarty dan Aida Fitalaya s. Hubeis (ed), Dinamika Wanita Indonesia: multidimensional, Jakarta: Pusat Pengembangan Sumber Daya Wanita, 1990.

Qaradawi, Yusuf al-,Fatwa-fatwa Kontemporer, alih bahasa As'ad Yasin, Jakarta: Gema Insani Press, 1996.

Qardhawi, Yusuf al-, Ruang Lingkup Aktivitas Wanita Muslimah, diterj. oleh Moh. Suri Sudahri dan Entin Rani'ah Ramelan dari judul asli Markazul Mar'ati fil Hayah al-Islamiyyah, cet. Ke-1 Jakarta: PUSTAKA KAUTSAR, 1996, hlm. 224.

Salim, Peter. Salim, Yeni. Kamus Besar Bahasa Indonesia Kontemporer, Jakarta: English Press, 1991.

Shihab, M. Quraish, Membumikan Al-Qur'an: Fungsi dan Peran Wahyu dalam Kehidupan Masyarakat, Bandung: Mizan, 1994.

Umar, Nasarudin, Argumen Kesetaraan Gender: Perspektif Al-Qur'an, Jakarta : Paramadina, 1999.

Wijaya, Aksin, Menggugat Otentisitas Wahyu Tuhan:Kritik Atas Nalar Tafsir Gender, Yogyakarta: Safiria Insania Press, 2004.

Yanggo, Huzaemah T., Fiqih Perempuan Kontemporer, Yogyakarta: Almawardiprima, 2001. 